\title{
Shopping-centre attributes affecting male shopping behaviour
}

Recerved (in revised form) 8 fuly 2005

\section{Sim Loo Lee}

is an associate professor and head of the Real Estate Department, School of Design and Environment, National University of Singapore. Her research interests include institutional analysis of real estate markets, retail planning and consumer behaviour and urban planning development and management.

\section{Muhammad Faishal Ibrahim}

is an assistant professor in the Department of Real Estate, School of Design and Environment, National University of Singapore. His areas of research include property valuation and behavioural real estate studies in the retail and residential property markets, and land transport issues.

\section{Chong Hsueh-Shan}

is a graduate from the Department of Real Estate, School of Design and Environment, National University of Singapore.

\begin{abstract}
Although there is an extensive body of literature on shopper orientation and consumer behaviour, research relating to male shoppers has been neglected. This study attempts to provide in-depth insights into retailer factors that have an influence on male shopping enjoyment. In particular, men place great importance on attributes such as 'cleanliness of the shopping centre', 'high-quality customer service' and 'good product knowledge of sales personnel'. The results suggest that 'shopping-centre features', 'ancillary facilities', 'value-added features' and 'special events' are the broad retailer categories that are significant in affecting male shoppers' enjoyment. In addition, the weighted factor rating analysis shows that male shoppers consider the 'shopping-centre features' as relatively more important than the rest of the broad factors. The findings provide useful implications for retail management and marketing strategies.
\end{abstract}

\section{Keywords:}

male shoppers, shopping-centre attributes, Singapore

Dr Muhammad Faishal Ibrahim Department of Real Estate

School of Design and Environment National University of Singapore

Singapore 117566

Tel: +6568746901

Fax: +6567748684

E-mail: faishal@nus.edu.sg

\section{INTRODUCTION}

Competition in the retail environment is intense. The apparent homogeneity of shopping centres (ie in terms of merchandise 
Intensifying competition

\section{Male shopping orientation and behaviour}

offerings and retailing formats), coupled with an increasingly wellinformed and demanding consumer population, only serve to intensify this level of rivalry further. To ensure survival in the face of keen competition there is a crucial need for retailers and developers to differentiate themselves from the mass by offering innovative retailing concepts as well as recognising new markets.

One of the most attractive segments identified recently is the men's market. According to Schneiderman, ${ }^{1}$ dollar sales for men's apparel in 1998 gained 6.8 per cent over 1997 , compared to only 3.7 per cent for the women's market. Research conducted by the J. C. Williams Group ${ }^{2}$ indicated that men accounted for two-thirds of all online spending in 2000 . Dholakia et $a l^{3}$ also observed that men are becoming increasingly visible in retail venues, with 10 per cent of men claiming to be primary grocery shoppers in their families and over half buying their own clothes. Furthermore, one of the hallmarks of post-modernity is a preoccupation by consumers with constructing and enhancing their sense of identity through the display of purchased goods. ${ }^{4}$ Reekie ${ }^{5}$ recently observed that it is possible for a man to simultaneously engage in consumer behaviour and maintain his masculine identity'. Consequently, it is not exaggerating to say that for retailers and developers to boost their bottom line, men will be the next hot consumer group to target.

Yet while men may be active in the marketplace, men's shopping behaviour per se has received little or no attention in the literature. It is contended in this study that in order to succeed in capturing the niche for men, there is a need for retailers and developers to have a better understanding of this segment.

Although there is copious academic literature on shopper orientation and consumer behaviour, male shoppers, while constituting a large segment of the population, have attracted very little attention hitherto. This apparent skewness in research direction is inextricably linked to the traditional belief that male shoppers are generally considered recalcitrant or unenthusiastic consumers and hence, from a retail management perspective, the pursuit of male shoppers is liable to be a complete waste of time and resources.

Set against this, however, are more recent studies which have unveiled ample evidence that points towards an increase in male participation in shopping-related activities. This is reflective of the trend where men are assuming a more egalitarian role due to gender role transcendence as well as facing increasing pressure to share the shopping duties in today's time-crunched world. Given that males are likely to feature more prominently in the retail scene, research on male shopping orientation and behaviour is imperative. Such research will provide the necessary information for assisting retailers to devise appropriate and localised marketing strategies aimed at reaching the attractive male market.

Most studies on gender and shopping orientation or behaviour have been rooted in the USA. In Singapore, research to investigate 
the relationship between gender and shopping orientation or behaviour is, however, modest. Given that Singapore's retail environment, demographics and cultural background may differ from the USA in several ways, there is a need to investigate similar issues in the local context.

The objective of this research is to determine the retailer attributes that will contribute to male shoppers' enjoyment. Implications for retail management and marketing strategies will be drawn from the findings.

\section{RELEVANT LITERATURE}

The literature is replete with studies indicating that consumers may view either shopping in general or specific shopping experiences as entertainment or recreational. ${ }^{6}$ Generally, studies involving shopping and entertainment can be classified into two research streams: viewed as an enduring tendency or trait, or as a motive for a particular shopping trip.

\section{Enduring tendency or trait}

One consideration in people's orientation towards shopping is their view of alternative uses and expenditure of time. Do they enjoy spending time shopping, or do other alternative uses of their time have higher priority? Previous research into shopper orientations has typically created a category reflecting an entertainment orientation supporting the notion that some shoppers have an enduring tendency to shop for entertainment purposes.

Dating from the pioneering analysis of Stone,$^{7}$ four types of shoppers have been identified, namely the economic shopper, the personalising shopper, the ethical shopper and the apathetic shopper. Stone's typology still has considerable merit, although changing consumers as well as the changing environment may have altered these basic orientations. Bellenger et al. ${ }^{8}$ suggested that much could be learned about retail patronage behaviour from the study of consumers' general shopping orientations, and they introduced the dichotomy of recreational and economic shopping. Bellenger and Korgaonkar ${ }^{9}$ contributed additional insights into the characteristics of recreational shoppers. They defined recreational shoppers as those who enjoy shopping as a leisure-time activity; while economic shoppers dislike shopping or are neutral towards it.

Lesser and Hughes ${ }^{10}$ found, both in their multi-market study and in the review of shopper typology literature, that active and inactive shoppers were the two types of shoppers which appear most often. Recreational shopping ${ }^{11}$ and purchasing involvement ${ }^{12}$ are two traits that distinguish active shoppers from inactive shoppers, and both traits have proven to be important predictors of consumer behaviour. This stream of research emphasises that shoppers possess general tendencies regarding the shopping process that are consistent across situations. This research tradition on shopper orientations has typically uncovered a host of weird and wonderful 
Motivational typology

\section{Experiential motives}

shopper types, ranging from those who 'like' to those who 'dislike' shopping.

\section{Motive for a particular shopping trip}

Apart from consumer orientations, another research stream has focused on consumer motivations for specific shopping trips. In contrast with the shoppers' enduring tendencies to enjoy the shopping process, the typologies focusing on consumer shopping motivations are more situational specific. The variety of shopping motives that have been suggested in the literature ${ }^{13}$ are summarised and framed by the motivational typology described by Westbrook and Black. ${ }^{14}$ This typology posits that shopping motives fall into three categories: product-oriented, experiential and a combination of product and experiential. In the first case, a store visit is motivated by purchase needs or the desire to acquire product information. The second class of motives in the typology has a hedonic or recreational orientation. Here, the attention is on store or mall visits made for the pleasure inherent in the visit itself. The last motive category occurs when the store visitor seeks to satisfy a purchase need as well as enjoying a pleasurable recreational experience in the outlet.

Likewise, Dawson et al. ${ }^{15}$ posited that some consumers have experiential motives for shopping which result from hedonic or recreational motivations. Through a survey of visitors to a large outdoor crafts market, the results clearly show that consumers with strong product or experiential motives report the most pleasure and arousal in the marketplace. Thus, those consumers who purposely come to the market to experience sights, sounds and people reported higher arousal and pleasure than consumers who did not have strong experiential motives. A positive emotional state that consists of high levels of pleasure and arousal is a key part of the shopping experience for consumers.

Researchers have discovered that people typically shop for both hedonic or recreational outcomes, and utilitarian outcomes, and that a positive mood can result from consumers pursuing either type of shopping value. ${ }^{16}$ Hedonic shopping motives are based on the quality of the shopping experience itself rather than on information gathering or purchasing products. ${ }^{17}$ Finally, Bloch et $a l^{18}$ found that consumers view malls as a place not only for shopping but also for other activities, such as entertainment, socialising with friends and browsing with no intentions of buying. These multiple motives inherent within a single shopping trip clearly indicate the entertaining capabilities of shopping.

\section{Factors inducing entertaining shopping experiences}

Several characteristics of entertaining shopping experiences have been previously investigated in isolation, for example, browsing, ${ }^{19}$ the retail environment, ${ }^{20}$ social interactions ${ }^{21}$ and bargains. ${ }^{22} \mathrm{~A}$ first attempt at organising a framework to help further understand 
Retailer and customer factors

\section{Environmental}

\section{Triangulation}

entertaining shopping experiences was carried out by Jones. ${ }^{23} \mathrm{He}$ adopted the critical incident technique in his exploratory research in identifying the factors contributing to the entertaining nature of shopping: 724 incidents were collected and two broad groups including nine unique factors were found to be characteristic of entertaining shopping experiences. The two broad groups were retailer factors and customer factors. Retailer factors include selection, prices, store environment and salespeople, while customer factors include social, task, time, involvement and financial resources. Interestingly, customer factors were mentioned more often than retailer factors in respondents' descriptions of entertaining shopping experiences.

Previous research has suggested that the physical environment of malls is an important determinant of patronage behaviour. ${ }^{24}$ This may influence consumers' emotional states ${ }^{25}$ and thereby have important effects on their behavioural responses. Similarly, Mehrabian and Russell ${ }^{26}$ state that the retail environment has the ability to influence the levels of pleasure and arousal experienced by consumers, which in turn mediate their desire to affiliate with others in the setting and their willingness to spend money or time.

The linkage between the physical environment and emotional responses is also supported by store-level research. Baker et al. ${ }^{27}$ established the relationship between store environment, the affective states of pleasure and arousal and behavioural intentions. Their study indicates that visual elements of retail stores, such as architecture, layout and signage, have important effects on store patronage decisions and quality inferences.

Darden and Babin ${ }^{28}$ found that a store's tangible characteristics can also influence resource expenditures and shopping value. If store-level environments influence emotions and responses, the more encompassing physical environment of the mall should also influence affective states (ie enjoyment and excitement).

\section{RESEARCH METHODOLOGY}

This study used more than one method, with the goals of achieving confirmation and completeness, often referred to as triangulation. ${ }^{29}$ It used a two-phase QUAL/QUAN sequential mixed-method design, essentially a step-wise progression from qualitative to quantitative. In-depth interviews were used in the qualitative phase and a structured questionnaire in the quantitative phase.

\section{In-depth interviews}

In-depth interviews were conducted with male shoppers to draw up an inventory of possible retailer attributes that can increase the interest factor in shopping for males. A sample of $20-40$ interviews was deemed sufficient; ${ }^{30}$ thus for this study 30 shoppers were interviewed. The main selection criterion for the interview was that male respondents had to be between the ages of $20-35$, as past literature has revealed that this is the most attractive target group 
Table I: Sample constituents of in-depth interviews

\begin{tabular}{lll}
\hline Shopping centre & Target & Obtained \\
\hline $\begin{array}{l}\text { Downtown } \\
\text { Ngee Ann city }\end{array}$ & 6 & 6 \\
$\begin{array}{l}\text { Regional centre } \\
\quad \text { Tampines Mall } \\
\begin{array}{l}\text { Sub-regional centre/new town centre } \\
\text { Jurong Point }\end{array}\end{array}$ & 6 & 6 \\
$\begin{array}{l}\text { Neighbourhood centre } \\
\text { Sun Plaza }\end{array}$ & 6 & 6 \\
$\begin{array}{l}\text { Precinct shops } \\
\text { Yew Tee Shopping Centre }\end{array}$ & 6 & 6 \\
Total & 6 & 6 \\
\hline
\end{tabular}

Door-to-door interviews because they have relatively high purchasing power coupled with a propensity to spend. Six informants who fulfilled the criteria were selected from each class of the shopping centres (Table 1).

\section{Structured questionnaire}

A structured questionnaire was used for door-to-door interviews. A pilot survey was conducted with ten representatives of the target respondents to check for ambiguities and problems inherent in the questionnaire. After two pre-tests and subsequent revisions of the survey instrument, the formal survey was developed. In total 478 questionnaires were completed, of which 419 were usable. The questionnaire consisted of different sections, each of which was designed to address a specific aspect.

The questionnaire was devoted to measuring the importance of each retailer attribute in contributing to male shoppers' shopping enjoyment. Using semantic differential scaling, these attributes were operationalised on a seven-point scale which ranged from 'not at all important' to 'very important'. The constructs were derived from the qualitative research as well as past studies. Another section concerned itself mainly with exploring the respondents' shopping behaviour and patterns, such as the average duration per shopping trip, the average amount spent per trip and the day and time that they normally shopped. The final section of the questionnaire was devoted mainly to determining the demographic characteristics of the respondents for the purpose of classification. Variables included room type, marital status, age, ethnic group, occupation and monthly gross household income.

\section{Definition of population and identification of sampling frame}

The target population for this study was all male residents living in Singapore aged 20 to 35 years old. The sampling frame (a sampling frame is the list from which elements are drawn) was constructed using the residential properties listing found in the Housing Development Board's (HDB's) latest annual report (2000 2001). The rationale for this decision was that a majority ( 86 per 


\section{Cluster sampling}

\section{Random sampling}

Stratified sampling cent) of the population in Singapore live in HDB flats. ${ }^{31}$

Furthermore, information on the number and distribution of HDB residential properties is readily available and easily accessible.

\section{Sample size}

The required sample size can be determined using the statistical formula below: ${ }^{32}$

Sample size $(n)=Z^{2}(p q)^{2} /(T)^{2}$

where

$p=$ estimated proportion of individuals displaying the characteristic of interest

$q=1-p$ (ie proportion of individuals in the population not displaying the characteristic of interest)

$T=$ sampling error

$Z=$ standard deviation for the desired precision or level of confidence.

Assuming a standard error of 1.96 (ie 95 per cent confidence level), a sampling error of 0.05 and a population proportion of 0.5 , the required sample size will be 384 . A sample size of 500 was proposed for this study, however, after taking into account other factors.

\section{Sampling technique}

The sampling process took place in multiple stages. First, cluster sampling was used. Five large clusters, namely the Central Region and Woodlands (Northern Region), Tampines (Eastern Region), Jurong East (Western Region) and Seletar (North Eastern) regional centres, were extrapolated (this is based on the Urban and Redevelopment Authority's planning area demarcations, in which Singapore is divided into the Central Region, regional centres and new towns).

Next, using simple random sampling, Jurong East regional centre (which comprises eight subzones) was randomly selected from the five clusters. Adopting simple random sampling yet again, Choa Chu Kang new town was randomly selected from the eight clusters (Figure 1).

Subsequently, stratified random sampling with regard to the different room types within Choa Chu Kang new town was carried out in a bid to obtain a sample that closely approximated the social characteristics (ie in terms of household income, occupation etc) of Singaporeans. The researcher sought to obtain a strata sample that was in the same proportion as that found in Choa Chu Kang new town in reality (Table $2^{33}$ ). Therefore, a proportional stratified sample was taken for this study.

\section{DATA ANALYSIS}

For the quantitative phase, the survey results were processed by the Statistical Package for Social Sciences (SPSS Version 10.0). Three analytical techniques for data analysis, namely descriptive statistics, 


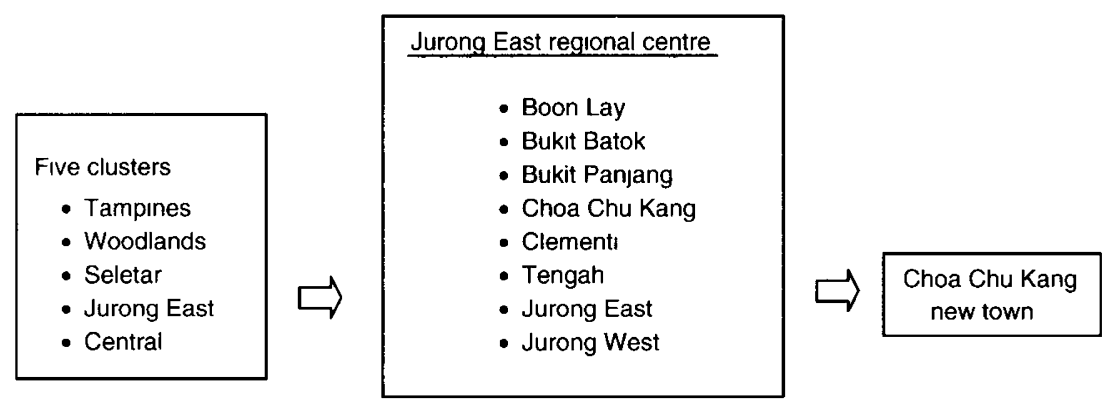

Figure 1: Multi-stage sampling procedure

Table 2: Proportion of each room type in Choa Chu Kang new town versus proposed sample size for each strata

\begin{tabular}{lcrrr}
\hline Room type & No. of units & $\%$ & $\begin{array}{l}\text { Proposed sample } \\
\text { size }\end{array}$ & $\%$ \\
\hline Three-star & 1,307 & 3.7 & 18 & 3.7 \\
Four-star & 17,897 & 51.2 & 256 & 51.2 \\
Five-star & 11,074 & 31.7 & 159 & 31.7 \\
Executive & 4.668 & 13.4 & 67 & 13.4 \\
Total & 34.946 & 100.0 & 500 & 100.0 \\
\hline
\end{tabular}

bivariate analysis and multivariate analysis, were adopted.

Descriptive statistics were used in the tabulation of the mean scores of all the variables. Analysis of variance (ANOVA) was utilised to determine whether there were statistically significant differences of means between two or more groups of scores. Next, utilising the ratings of the constructs in determining males' shopping orientation as the data input, the results of the factor analysis were presented.

\section{SHOPPING-CENTRE FACTORS}

This section presents the discussion and analysis of the main findings from the questionnaire of the quantitative research. First, descriptive statistics were used to determine the relative importance of each retail mall attribute in making male shoppers' experience an enjoyable one. Subsequently, factor analysis was conducted to investigate the underlying latent dimensions or constructs that account for the set of variables. Lastly, the researcher attempted a comparative analysis (via hypothesis testing) through ANOVA to examine if different socio-economic groups perceive the importance of individual retail mall attributes differently.

\section{Importance ratings}

Respondents were asked to rate, on a seven-point Likert scale (where 1 indicates 'not important at all', 4 indicates 'neutral' and 7 indicates 'very important'), the importance of each retail mall

\section{Descriptive statistics} attribute in contributing to shopping enjoyment.

Table 3 shows, in descending order, the mean importance scores that accrued to each of the 18 shopping-centre attributes as rated 
Table 3: Mean scores of importance

\begin{tabular}{lll}
\hline Shopping-centre attributes & Mean & Standard deviation \\
\hline 1. Cleanliness & 5.53 & 137 \\
2. High-quality customer service & 5.46 & 1.38 \\
3. Good product knowledge of sales personnel & 5.43 & 1.34 \\
4. Friendly design layout & 5.36 & 1.28 \\
5. Wide variety of stores & 5.23 & 1.32 \\
6. Pleasant ambience (eg lighting) & 5.22 & 1.35 \\
7. Avalability of eating outlets/restaurants/cafes & 4.86 & 142 \\
8. Avallability of sales, promotions, discounts, bargans & 4.84 & 1.29 \\
9. Spaciousness of internal layout & 4.83 & 1.42 \\
10. Late closing hours & 4.69 & 1.27 \\
11. Unique tenant mix & 4.63 & 1.39 \\
12. Ease of finding car-parking lots & 4.62 & 1.67 \\
13. Avallability of entertannment facilities & 4.59 & 1.40 \\
14. Unique store design & 4.58 & 1.40 \\
15. Ability to charge credit & 4.51 & 1.56 \\
16. Availability of ancillary facilities (eg banking) & 4.47 & 1.45 \\
17. Avalability of roadshows to learn about product features and trends & 391 & 1.40 \\
18. Avallability of celebrations, activitles and functions & 3.90 & 1.48 \\
\hline
\end{tabular}

\section{Ratings of attributes}

\section{Cleanliness of shopping centres}

\section{Customer service}

by the 419 male respondents. Sixteen out of the 18 attributes obtained a mean score greater than 4 . This implies the significance of these variables in contributing to the level of enjoyment experienced by men during their shopping trip. It also proves the validity of the constructs (derived from the qualitative research phase) used in the questionnaire and ensures that the results have practical significance.

The mean scores of all attributes ranged from 3.90 to 5.53, with the variable 'cleanliness of shopping centres' topping the list of importance ratings. It is not surprising that the respondents valued 'cleanliness' over other attributes. This is because, given the relatively high standard of living in Singapore (as a result of rising affluence of the society), it may seem intuitive that the hygiene factor plays a crucial role in influencing the level of shopping enjoyment. Dingy malls project a poor image and undoubtedly will have a negative impact on the level of shopping enjoyment.

The variable 'high-quality customer service' trailed at a close second with a mean score of 5.46. This may be explained by the fact that the younger Singaporeans (all male respondents were between the ages of 20 and 35), being more educated and cosmopolitan, are becoming increasingly savvy and demanding. Recognising that this is an age where consumers reign (due to intense competition in the marketplace), they expect more out of service providers. Thus the provision of value-added features by retailers such as excellent customer service may be deemed a pertinent criterion when evaluating the level of shopping enjoyment. Also, this emphasis on high-quality customer service may seem logical and comprehensible if one associates it with men's psychological make-up. Since the need for respect and a sense of power and control characterises men in general, ${ }^{34}$ it is unsurprising that they may wish to make use of the retail setting to exercise their 


\section{Physical and atmospheric dimensions}

\section{Value-added facilities}

\section{Special events at shopping centres}

authority - by having salespersons to pander to their needs. But it may also be due to a sense of incompetence that men experience in the shopping domain that makes them desire the help of salespersons - in order to absolve them from the hassle and difficulties of performing a purchase act.

Other shopping-centre attributes which occupy the few top notches relate to the physical and atmospheric dimensions of the shopping centres. They are 'good product knowledge of sales personnel', 'friendly design layout', 'wide variety of stores' and 'pleasant ambience'. All of these variables obtained high mean scores of above 5, which is not difficult to rationalise given their prominence in shaping the retail environment and hence enjoyment level.

Appearing in the middle of the importance list are variables such as 'availability of eating outlets', 'availability of sales and promotions', 'late closing hours', 'unique tenant mix' and 'ease of finding car-parking lots'. The mean score of these six variables averaged 4.75. This figure, although less than 5, is still way above 4 . It thus indicates that while value-added features are subservient to physical or atmospheric factors, they are still substantially valued by male shoppers. Given that value-added facilities serve to enhance the shopping experience through the convenience they bring to shoppers, it is little wonder that they constitute an important component within the consideration set when evaluating shopping enjoyment.

As for variables such as 'availability of entertainment facilities', 'unique store design', 'ability to charge credit' and 'availability of ancillary facilities', they bottomed the list with their relatively low mean scores. But it is perhaps more interesting to draw attention to the two variables that contended the last two positions on the mean score list, since they are the only two attributes, out of the 18 , which have mean scores of below 4 . They are 'availability of roadshows to learn about product features and trends' and 'availability of celebrations and activities', with low mean scores of 3.91 and 3.90, respectively. This signifies that special events hosted by shopping centres are of secondary importance in influencing the level of shopping enjoyment, perhaps due to the fact that men generally dislike crowds and noise. One point to note is that although these two variables are deemed to be less important in affecting shopping enjoyment, the shortfall of only about 0.10 from the neutral score of 4 suggests that they are features not to be belittled or disregarded.

From the results, it may appear that variables which relate either to the physical dimension or the intangible atmospheric element of shopping centres are given slightly heavier weightage compared to variables which constitute value-added features. This is, however, a rather crude conclusion because a closer examination will reveal that the mean scores of all the attributes actually do not deviate much. This means that it is not exactly fair to place a judgment on 


\section{Principal component analysis}

the importance of individual retailer attributes simply based on the rankings. The slight discrepancy in mean scores of the attributes also goes to show that respondents tend to view the retail environment in a holistic manner and the enjoyment factor does not hinge on any single attribute in particular. In other words, all attributes contribute to the male shoppers' entertaining shopping experience and none should thus be overlooked. Another qualification as to why the rankings are not to be taken at face value is that they are, to a certain extent, sensitive to the specific characteristics of each respondent.

\section{FACTOR ANALYSIS}

Utilising the importance ratings of the attributes in influencing the entertaining shopping experience as the data input, the results of the factor analysis will be presented in the next three sections. Table 4 summarises the solutions to the principal component analysis of the retailer attributes. The factor loadings of the attributes, percentage of variance explained, coefficient alpha, the Bartlett's test of sphericity and Kaiser-Meyer-Olkin (KMO) measure of sampling adequacy are listed in the table.

Table 4: Latent dimensıons of retail mall attributes

\begin{tabular}{|c|c|c|}
\hline Factor/label & Retail mall attributes & Factor loadings \\
\hline \multirow[t]{2}{*}{ Factor 1: Shopping-centre features } & High-quality customer service & 0.825 \\
\hline & Friendly design layout & 0.784 \\
\hline \multirow[t]{2}{*}{ Varrance. 35.75 per cent } & Pleasant ambience & 0779 \\
\hline & Good product knowledge of sales personnel & 0.744 \\
\hline \multirow[t]{2}{*}{ Coefficient alpha: 0.90} & Cleanlıness & 0.724 \\
\hline & Spaciousness of internal layout & 0.713 \\
\hline \multirow[t]{3}{*}{ Weighted factor rating: 5.86} & Wide variety of stores & 0.619 \\
\hline & Unıque tenant $\mathrm{mix}$ & 0.600 \\
\hline & Unique store design & 0.501 \\
\hline Factor 2: Ancillary facilities & Avallability of entertanment facilities & 0734 \\
\hline \multirow[t]{2}{*}{ Varıance: 10.17 per cent } & Avallability of eating outlets/restaurants/cafes & 0.725 \\
\hline & Avaliability of ancillary facilities (eg banking) & 0.706 \\
\hline \multicolumn{3}{|l|}{ Coefficient alpha: 0.71} \\
\hline \multicolumn{3}{|l|}{ Weighted factor ratıng: 4.63} \\
\hline Factor 3: Value-added features & Ability to charge credit & 0.822 \\
\hline \multirow[t]{2}{*}{ Varıance: 9.66 per cent } & Ease of finding car-parking lots & 0806 \\
\hline & Late closing hours & 0.785 \\
\hline \multicolumn{3}{|l|}{ Coefficient alpha: 0.76} \\
\hline \multicolumn{3}{|l|}{ Weighted factor ratıng: 4.60} \\
\hline Factor 4: Special events & Avaliability of celebrations, activities and functions & 0.877 \\
\hline (atmosphere) & Avallability of roadshows to learn about product & \\
\hline Variance: 6.76 per cent & features and new trends & 0.807 \\
\hline \multirow[t]{2}{*}{ Coefficient alpha: 0.71} & Avallability of sales, promotions, discounts and & \\
\hline & bargaıns & 0.560 \\
\hline \multicolumn{3}{|l|}{ Weighted factor ratıng: 4.14} \\
\hline \multicolumn{2}{|l|}{ Bartlett's test of sphericity } & 0.000 \\
\hline \multicolumn{2}{|c|}{ Kasser-Meyer-Olkın measure of sampling adequacy } & 0.850 \\
\hline \multicolumn{2}{|c|}{ Total varıance } & $62.33 \%$ \\
\hline
\end{tabular}




\section{Shopping centre features}

\section{Ancillary features}

Value-added features

\section{Special events}

\section{Shopping-centre factors}

The values of the Bartlett's test of sphericity $(0.000)$ and KMO measure of sampling adequacy (0.850) indicate that the data are appropriate for factor analysis. Using principal component analysis as the extraction method and varimax with Kaiser normalisation as the rotation method, factor analysis yielded four retailer factors with eigenvalues greater than 1. Each of the factors also proved interpretable. Their cumulative percentage of variance amounted to 62.33 per cent. Coefficient alpha scores for factor 1 , factor 2 , factor 3 and factor 4 were $0.90,0.71,0.76$ and 0.71 , respectively. Since all four factors had coefficient alpha scores that exceeded 0.65 (which is a yardstick for reliability according to Dawson et al. ${ }^{35}$ ), they were held to be acceptable.

Factor 1 accounts for 35.75 per cent of the variance within the original set of variables and it can most aptly be labelled as 'shopping-centre features'. This is because factor 1 comprises variables such as 'high-quality customer service', 'friendly design layout', 'pleasant ambience', 'good product knowledge of sales personnel', 'cleanliness', 'spaciousness of internal layout', 'wide variety of stores', 'unique tenant mix' and 'unique store design'.

Factor 2 accounts for 10.17 per cent of the variance within the original set of variables. This dimension can best be labelled as 'ancillary facilities' because it principally consists of variables such as 'availability of entertainment facilities', 'availability of eating outlets/restaurants/cafes' and 'availability of ancillary facilities (eg banking)'.

Factor 3 can be categorised as 'value-added features' since the variables under this dimension are 'ability to charge credit', 'ease of finding car-parking lots' and 'late closing hours'. It explains 9.66 per cent of the variance within the original set of variables.

Factor 4 accounts for 6.76 per cent of the total variance within the original set of variables and it principally relates to special events (ie atmosphere) organised by shopping centres. It incorporates variables such as 'availability of celebrations, activities and functions', 'availability of roadshows to learn about product features and new trends' and 'availability of sales, promotions, discounts and bargains'.

Table 4 also indicates the weighted factor rating (WFR) of each of the factors. ${ }^{36}$ This refers to the weighted mean score of the factors produced by the factor analysis. It shows the weighted respondents' importance ratings of the broad factors which affect male shopping enjoyment.

According to Ibrahim, ${ }^{37}$ while the factor analysis produces the importance rating structures within the retail mall attributes affecting male shopping enjoyment, it does not indicate the mean score ratings of the factors which are produced by its procedures. The factor scores and loadings produced by the factor analysis have no clear equivalence to the mean score ratings of the respondents. The WFR is computed as follows: 


\section{Weighted factor rating}

\section{Analysis of variance}

$$
K=\frac{\sum_{j=1} \mu_{j k} f_{l k}}{\sum_{\jmath=1} f_{j k}}
$$

where

$\mu_{j k}=$ mean score rating of variable $j$ in factor $k$

$f_{j k}=$ factor loading of variable $j$ in factor $k$.

Table 4 shows that the factor 'shopping-centre features' recorded the highest WFR, followed by the 'ancillary facilities', 'value-added features' and 'special events'.

The above analysis shows that factor 1 is the single best summary of linear relationships exhibited in the data because the particular combination of original variables accounts for more of the variance in the data as a whole than any other linear combination of variables. It also has a high coefficient alpha score of 0.90 , which indicates very high reliability. In addition, via the WFR analysis, factor 1 recorded the highest score which implies its relative importance. In contrast, factor 4 accounts for a comparatively low proportion of the total variance. Its relatively lower coefficient alpha also makes it the least well-defined dimension, indicating that perhaps the scale items in the questionnaire need to be extended to scope the dimension better. It also has the lowest WFR score.

Table 5 summarises the research findings for the analysis of the shopping-centre factors against the shopping patterns. At a 0.05 level of significance, the ANOVA procedures indicate that certain cases reveal statistically significant differences. For the mean score ratings of 'shopping-centre features', the differences occur in age, marital status and occupation. For the mean score ratings of 'ancillary facilities', the difference lies in room type and occupation. But, for the mean score ratings for 'value-added features', none of the results is significantly different. Significant differences in the mean score ratings for 'special events' occur in occupation and monthly household income.

The findings are consistent with the conceptual framework which was developed in the qualitative phase of the study as 16 out of 18 shopping-centre attributes recorded mean scores of above 4 . This implies the importance of these variables in influencing shoppers' enjoyment. In particular, respondents placed high importance on attributes such as 'cleanliness', 'high-quality customer service', 'good product knowledge of sales personnel', 'friendly design layout', 'wide variety of stores' and 'pleasant ambience'. Each of these variables had a mean score of above 5. Also, the 18 retailer attributes were subjected to the process of factor analysis and four broad dimensions were identified, namely ' shopping-centre features', 'ancillary features', 'value-added features' and 'special events'.

ANOVA tests were also conducted for two purposes: to verify if groups of different socio-economic characteristics perceive the importance of the factors in affecting their shopping enjoyment 
Table 5: Summary of ANOVA results of shopping centre factors and demographics

\begin{tabular}{|c|c|c|c|c|}
\hline Factors & $\begin{array}{l}\text { Shopping-centre } \\
\text { features }\end{array}$ & $\begin{array}{l}\text { Ancillary } \\
\text { facilities }\end{array}$ & $\begin{array}{l}\text { Value-added } \\
\text { features }\end{array}$ & $\begin{array}{l}\text { Special events } \\
\text { (atmosphere) }\end{array}$ \\
\hline \multirow[t]{2}{*}{ Age } & $F=7.543$ & $F=0.198$ & $F=2.901$ & $F=1764$ \\
\hline & $p=0.000^{*}$ & $p=0.820(n s)$ & $p=0.056$ (ns) & $p=0.173(\mathrm{~ns})$ \\
\hline \multirow[t]{2}{*}{ Race } & $F=0.360$ & $F=1.136$ & $F=0.299$ & $F=2.227$ \\
\hline & $p=0.782(\mathrm{~ns})$ & $p=0.334$ (ns) & $p=0.826(n s)$ & $p=0.085(n s)$ \\
\hline \multirow[t]{2}{*}{ Marital status } & $F=22.97$ & $F=5.960$ & $F=1.313$ & $F=2.273$ \\
\hline & $p=0.019 *$ & $p=0.863(n s)$ & $p=0.270$ (ns) & $p=0.104(n s)$ \\
\hline \multirow[t]{2}{*}{ Room type } & $F=2.403$ & $F=3.157$ & $F=0.652$ & $F=0.584$ \\
\hline & $p=0.092(n s)$ & $p=0.003^{\star}$ & $p=0.713$ (ns) & $p=0.791$ (ns) \\
\hline \multirow[t]{2}{*}{ Occupation } & $F=4.109$ & $F=2.502$ & $F=1.107$ & $F=2.768$ \\
\hline & $p=0.000^{*}$ & $p=0.017^{*}$ & $p=0.359$ (ns) & $p=0.009 *$ \\
\hline Monthly household & $F=1.406$ & $F=0.640$ & $F=0.655$ & $F=3.172$ \\
\hline income & $p=0.194(n s)$ & $p=0.723$ (ns) & $p=0.710(n s)$ & $p=0.003^{*}$ \\
\hline
\end{tabular}

* denotes significant difference where $p<0.05$

(ns) denotes no significant difference where $p>0.05$

Sales and promotion differently; and to discern if demographic variables have an impact on shopping orientation. In the former case, the tests showed that respondents with different socio-economic characteristics indeed considered the importance of the factors differently; in the latter case, it was also found that shoppers with different shopping orientations shared dissimilar demographic variables in certain aspects.

\section{CONCLUSION AND IMPLICATIONS}

The objective of this research was to determine the shopping-centre attributes that influence male shopping behaviour. As suggested by the results of this study, sales and promotions in shopping centres are activities that will add considerably to men's shopping enjoyment. Conventional retail wisdom holds that most men shun the traffic and long queues associated with sales. Thus, it would prove a good move to aim sales and promotions exclusively at men to empower them. For instance, shopping centres could host special promotional events with male themes. The management of shopping centres could hold joint events with clubs with a male following to entice them and build up mall loyalty. Retailers also could offer trade-in discounts when exact replacements are purchased so that men emerge like winners.

The factor analysis and WFR scores show the relative significance of the factor 'shopping-centre features' in influencing male shopping behaviour. Therefore, retailers and shopping-centre managers need to focus on the salient features of the shoppingcentre attributes. These include the quality of customer service, design layout, ambience, cleanliness and the tenant mix. Although the factors 'ancillary facilities', 'value-added features' and 'special events' scored relatively lower WFRs, they also deserve some attention as they recorded significantly high scores as well.

In addition, attributes relating to shopper circulation, 


\section{Socio-economic characteristics}

\section{Limitations of study}

merchandise configuration, colours, smells and music should all be manipulated to evoke men's feelings of empowerment and to let them emerge as winners. In other words, retailers and shoppingcentre managers should examine the underlying attributes in their entertaining and empowering capabilities so as to develop competitive marketing strategies to attract male shoppers.

The findings of the ANOVA analysis give a good insight into the varying significance attributed to the factors by male shoppers with different socio-economic characteristics. Specifically, there are significant differences in the mean scores of the factor "shoppingcentre features' among male shoppers from the different age and occupation groups. Retailers and shopping-centre managers should examine the mean scores in greater detail and use these findings to enhance their marketing strategies further to cater to the different needs of male shoppers.

As shopping activity is often conducted in pairs or groups, it is imperative that the needs of the various parties are provided for in the quest for high and sustainable patronage of the shopping centre. Particularly, if the needs of male shoppers are met, it would not be difficult to satisfy the requirements of female shoppers as 'shopping is in their blood'.

The results of this study provide an encouraging start in understanding male shopping orientations and behaviour in the Singapore context, but the study does have limitations.

First, the exclusion of private housing in the cluster sampling may have yielded a sample that was not broadly inclusive in terms of income groups and occupational status. This may have resulted in bias due to selection error. But, bearing in mind that nationwide samples based on stratifications of public housing were actually obtained and that only 14 per cent of the Singapore population live in private housing, the results do represent a broad cross-section of the society.

Secondly, the data collected during the qualitative research phase were based on respondents' recollections (eg respondents were asked to talk about a recent shopping trip that they recalled as being entertaining and enjoyable etc) and, as such, there is the probability of error in their responses due to recall effects. Likewise, the quantitative instrument also included retrospective questions with regard to the frequency of visits, duration of visits and amount of money spent. Again, responses to these questions might not be totally accurate due to forgetfulness among survey respondents. But given the high frequency of shopping, the negative influence of these factors is believed to be minimal.

Finally, even though considerable attention was given to identifying variables that could measure shoppers' orientations as well as those which would influence entertaining shopping experiences, it is possible that the inclusion of more variables could improve the constructs and hence the credibility of the study. Demographic variables such as household composition and 


\section{Non-entertaining shopping experiences}

household size were not tested in the study, but they certainly merit testing.

Moreover, as this research focuses only on the shopping-centre factors affecting entertaining shopping experiences, future research could be carried out to examine the factors affecting nonentertaining shopping experiences. Lastly, since past literature implies that most active online shoppers are men, another fruitful avenue for future research would be to investigate men's perceptions of entertaining shopping experiences by comparing internet shopping and store shopping, and contrasting the elements of satisfaction between the alternative shopping methods.

\section{References}

1 Schneiderman. I. P. (1999) 'Understanding today's male shopper (Why Men Buy 2)'. Daily' New's Record, 21 February.

2 BizRate.com (2001) 'J. C. Williams Group', avaılable at www.bizrate com, accessed October 2001.

3 Dholakıa, R. R., Perderson, B. and Hikmet, N (1995) 'Married males and shoppıng Are they sleeping partners?', International Journal of Retall and Distribution Management. Vol. 23, No. 3, pp. 27-33.

4. Miller, D (1998) A Theory of Shopping, Cornell University Press, Ithaca, NY.

5. Reekıe, G. (1992) 'Changes in the Adamless Eden', in Shields, R. (ed.) Lifestyle Shopping. The Subject of Consumption, Routledge, London, UK, pp 170-194.

6. Babın, B. J., Darden, W. R. and Griffin, M (1994) 'Work and/or fun: Measuring hedonic and utilitarian shopping value', Journal of Consumer Research, Vol. 20, No. 4. pp. 644656 .

7 Stone, G P (1954) 'City shoppers and urban identification: Observations on the social psychology of city life', American Journal of Sociology, Vol. 60, No 1, pp. 36-45.

8. Bellenger, D. N., Robertson, D. and Greenberg, B. A. (1997) 'Shopping centre patronage motives', Journal of Retailing. Vol. 53, No. 2, pp. 29-38.

9. Bellenger, D. N. and Korgaonkar, P. (1980) 'Profiling the recreational shopper', Journal of Retaling, Vol. 56, No. 3, pp. 77-92.

10. Lesser, J. A. and Hughes, M. A. (1986) 'Towards a typology of shoppers', Business Horizons, Vol. 29, No. 6, pp. 56-62.

11. Bellenger and Korgaonkar, ref. 9 above.

12 Slama, M. E. and Tashchian, A (1985) 'Selected socioeconomic and demographic characteristics associated with purchasing involvement', Journal of Marketing, Vol 49, No 1, pp. 72-82.

13. Tauber, E. M (1972) 'Why do people shop?', Journal of Marketing, Vol. 36, No. 4, pp. 46-49

14. Westbrook, R. A. and Black, W. C. (1985) 'A motivation-based shopper typology', Journal of Retailing, Vol. 61, No. 1, pp. 78-103

15. Dawson, S., Bloch, P. H. and Ridgway, N. M. (1990) 'Shopping motives, emotional states, and retail outcomes', Journal of Retailing, Vol. 66, No 4, pp. 408-427.

16. Babin et al., ref. 6 above.

17 Boedeker, M. (1995) 'New-type and traditional shoppers: A comparison of two major consumer groups', International Journal of Retall and Distribution Management, Vol 23, No. 3, pp. 17-26.

18. Bloch. P. H., Sherrell, D. L. and Ridgway, N. M. (1986) 'Consumer search: An extended framework', Journal of Consumer Research, Vol. 13, No. 1, pp. 119-126.

19. Bloch, P. H., Ridgway, N. M. and Sherrell, D. L. (1989) 'Extending the concept of shopping: An investıgation of browsing activity', Journal of the Academy of Marketing Science, Vol. 17, No. 1, pp. 13-21. 
20. Donovan, R. J., Rossiter, J. R., Marcoolyn, G. and Nesdale, A. (1994) 'Store atmosphere and purchasing behaviour', Journal of Retalling, Vol. 70, No. 3, pp. 283-294.

21. Bloch et al, ref. 19 above.

22. Schindler, R. M. (1989) 'The excitement of getting a bargain. Some hypotheses concerning the origins and effects of smart-shopper feelıngs', in Srull, T K (ed.) Advances in Consumer Research, Vol. 16, Association for Consumer Research, Provo, UT, pp. 447-453.

23. Jones, M. A. (1999) 'Entertainıng shopping experıence: An exploratory investigation', Journal of Retailing and Consumer Services, Vol. 6, No. 3, pp. 129-139.

24. McGoldrick. P. J. and Thompson, M. G (1992) Regional Shopping Centres 'Out-of-Town Versus In-Town, Avebury, Aldershot, UK.

25. Jacobs, J. (1984) The Mall An Attempted Escape from Everyday Llfe, Waveland Press, Prospects Heights, IL.

26. Mehrabian, A. and Russell, J. A. (1974) An Approach to Environment Psychology, MIT Press, Cambridge. MA.

27. Baker, J., Grewel, D. and Levy, M. (1992) 'An experimental approach to makıng retall store environmental decisions', Journal of Retailing. Vol. 69, No. 4. pp. 445-460.

28. Darden, W. R., and Babın, B J. (1994) 'Exploring the concept of affective quality: Expanding the concept of retall personality', Journal of Bustness Research, Vol. 29, No. 2. pp. 101-109.

29 Tashakkori, A. and Teddlıe, C. (1998) Mixed Methodology Combintng Qualtative and Quantitative Approaches, Sage Publications, Thousand Oaks, CA.

30 Walker, R (1985) 'An introduction to applied qualitative research', in Walker, R. (ed.) Applied Qualtatıve Research, Gower Publishing Company, Brookfield, VT.

31. Department of Statistıcs (2001) Key Facts and Figures, Department of Statistics, Singapore.

32. Kau, A. K., Tan, S. J. and Wirtz, J. (1998) Seven Faces of Singaporeans. Thetr Values, Aspirations and Lifestyles, Prentıce Hall, Singapore.

33. Housing and Development Board (2001) 'Data on Choa Chu Kang new town', avallable at www hdb.gov.sg.

34. Hirschman, E. C. (1999) 'The meanıngs of men', Semiotica, Vol 126, No 1, pp. 161-178.

35. Dawson et al., ref. 15 above.

36. Ibrahim, M F. (2002) 'Disaggregating the travel components in shopping center choice An agenda for valuation practices', Journal of Property Investment and Finance, Vol. 20, No 3, pp. 277-294.

37. Ibid. 